\title{
ANALISIS MODEL EKSPOR KOMODITAS PERIKANAN INDONESIA DENGAN PENDEKATAN GRAVITY MODEL
}

\author{
Subhechanis Saptanto ${ }^{1}$ dan Widyono Soetjitpto ${ }^{2}$ \\ ${ }^{1}$ Peneliti pada Balai Besar Riset Sosial Ekonomi Kelautan dan Perikanan \\ JI. KS Tubun Petamburan VI Jakarta 10260. \\ Telp. (021)53650162, Fax. (021)53650159 \\ ${ }^{2}$ Peneliti pada LPEM, Universitas Indonesia \\ Jl. Salemba Raya 4, Jakarta, 10430 \\ Tel. (021) 314 3177; Fax. (021) 334310 \\ Diterima 4 Desember 2009 - Disetujui 26 Juni 2010
}

\section{ABSTRAK}

Penelitian ini bertujuan untuk mengetahui potensi ekspor perikanan Indonesia di 28 negara tujuan ekspor dan faktor-faktor yang mempengaruhi nilai ekspor perikanan dengan menggunakan pendekatan Gravity Mode/ yang diaplikasikan dalam subsektor perikanan. Variabel-variabel yang digunakan antara lain nilai ekspor riil, GDP nominal, jumlah penduduk, jarak relatif, nilai tukar riil efektif dan interaksi antara tarif dengan dummy integrasi ekonomi. Metode analisis yang digunakan adalah analisis data panel dengan menggunakan fixed effect. Hasil penelitian menunjukkan bahwa secara umum seluruh variabel berpengaruh secara signifikan kecuali untuk variabel nilai tukar riil efektif Indonesia. Tanda variabel yang berlawanan dengan hipotesis adalah variabel jumlah penduduk mitra dagang yang seharusnya bernilai positif dan interaksi antara tarif dengan APEC yang seharusnya bernilai negatif. Peningkatan jumlah penduduk mitra dagang menyebabkan penurunan nilai ekspor. Variabel interaksi tarif dan APEC bernilai positif karena tujuan ekspor perikanan Indonesia lebih banyak ke Amerika Serikat dan Jepang yang memang merupakan anggota dari APEC. Berdasarkan hasil estimasi model dengan menggunakan fixed effect diperoleh informasi bahwa terdapat lima negara yang menjadi tujuan ekspor komoditas perikanan Indonesia, yakni Amerika Serikat, China, Mesir, Inggris dan Jepang.

Kata kunci : ekspor perikanan, gravity model, data panel

\section{Abstract : Analysis Model of Indonesian Fisheries Export Commodities by Gravity Model Approach . By: Subhechanis Saptanto and Widyono Soetjitpto}

This research aims to analyze export of fisheries products to 28 countries as potentials market and related factors on fisheries commodities export values by using Gravity Model approach. It uses several variables including export value, nominal GDP, population, real effective exchange rate, relative distance and interaction between tariff and dummy of economic integration. Method of analysis uses a panel data analysis with fixed effect. Results of this research show that all variables provide significant influences, except for real effective exchange rates on Indonesian currency. Trade partner population and interaction between tariff and APEC dummy are not in favor of the hypothesis. Increasing of trade partner population decreases value export. Interaction between tariff and APEC dummy increase value export because large proportions of fish export go United States of America and Japan and members of APEC. It means Indonesia can still export fisheries commodities even in increasing tariff. By using fixed effect approach, this research estimate big five targeted export countries namely United States of America, China, Egypt, England and Japan.

Keywords : fisheries export, gravity model, panel data 


\section{PENDAHULUAN}

Perdagangan internasional memiliki peranan penting bagi Indonesia karena aktivitas ekspor yang menjadi komponen utama dapat dijadikan salah satu sarana penggerak perekonomian. Ekspor dapat menghasilkan devisa negara untuk kesejahteraan rakyat. Kegiatan ekspor perikanan bertujuan untuk memperoleh devisa, menyerap tenaga kerja, memacu pertumbuhan sektor riil, memacu pertumbuhan ekonomi dan meningkatkan kesejahteraan rakyat. Manfaat ekspor bagi dunia usaha adalah memperluas pasar sehingga memperoleh potensi pasar yang lebih luas serta dapat memanfaatkan kelebihan produksi dan mengurangi kejenuhan pasar lokal. Berdasarkan urgensi dan permasalahan tersebut, dinilai perlu dilakukannya kajian dampak faktor-faktor yang mempengaruhi nilai ekspor komoditas perikanan Indonesia.

Pergeseran dalam pola perdagangan dunia tidak lagi hanya dengan mengikuti prinsip - prinsip supply-demand, tetapi juga dibentuk oleh isu - isu, konvensi, dan berbagai macam kesepakatan dan kerjasama internasional. Hal tersebut ditandai dengan terbentuknya blok-blok ekonomi seperti Uni Eropa, APEC, NAFTA, Mercosur, AFTA, kerjasama ASEAN dan blok-blok ekonomi lainnya.

Adanya blok-blok kerjasama itu juga dimaksudkan untuk mengantisipasi liberalisasi perdagangan dalam rangka memperkuat daya tahan perekonomian negara atau kawasan terhadap tantangan dan blok ekonomi lain.

Indonesia merupakan salah satu negara yang tergabung dalam kerjasama perdagangan APEC (Asia-Pacific Economic Cooperation) dan ASEAN (Association of Southeast Asia Nations). Suatu negara berhak membuat peraturan impor yang secara langsung maupun tidak langsung berpengaruh terhadap impor barang dan jasa. Tindakan pemerintah negara importir tersebut dapat berlaku secara bilateral ataupun multilateral, misalnya dalam penerapan tarif.

Adanya globalisasi dan liberalisasi perdagangan dunia mengakibatkan terjadi perubahan lingkungan strategis dimana globalisasi memberikan peluang melalui penurunan hambatan tarif dan non tarif serta dapat meningkatkan akses produk domestik ke pasar internasional. Globalisasi merupakan fenomena perkembangan ekonomi dunia yang mengindikasikan adanya saling membutuhkan di antara satu pihak dengan pihak lain selain itu juga menunjukkan adanya persaingan.

Fenomena globalisasi perdagangan memilik dua dampak. Pertama, globalisasi memberikan peluang karena terdapat penurunan hambatan tarif dan non tarif serta dapat meningkatkan akses produk domestik ke pasar internasional. Dampak lainnya adalah globalisasi dapat menghilangkan subsidi dan proteksi sehingga akan menyebabkan akses produk luar yang masuk ke pasar domestik secara bebas sehingga menimbulkan persaingan produk (Purnomo, 2007). Dalam rangka peningkatan pertumbuhan ekonomi dan mengurangi angka pengangguran salah satu upaya yang dapat dilakukan adalah pengembangan sektor perdagangan luar negeri dan pengembangan sektor riil.

Terjadinya fenomena globalisasi dan liberalisasi perdagangan dunia juga berdampak terhadap perekonomian Indonesia, yakni salah satunya adalah sektor agribisnis khususnya pada sub sektor perikanan. Pada periode akhir tahun 1990-an terjadi perubahan nilai ekspor produk-produk agribisnis yang berpengaruh signifikan terhadap kondisi perekonomian Indonesia. Pada saat terjadinya krisis ekonomi pada tahun 1997, neraca perdagangan ekspor pada subsektor perikanan Indonesia masih mengalami peningkatan dan terjadi surplus perdagangan yang mencapai 1,78 milyar dolar (Kusumastanto, 2002). Hal tersebut menunjukkan bahwa dalam kondisi yang perekonomian yang bergejolak sekalipun usaha di subsektor perikanan masih dapat bertahan. 
Ekspor komoditas perikanan Indonesia ke berbagai negara selalu mengalami perubahan tiap tahunnya. Tujuan utama ekspor perikanan Indonesia adalah Jepang dan Amerika Serikat. Negara lainnya adalah Singapura, Inggris, Perancis, Jerman, Belgia, Australia, Hongkong, China, Italia dan Saudi Arabia dan negara-negara lainnya. Untuk Jepang, rata-rata nilai ekspor perikanan Indonesia dari tahun 1996 hingga 2007 mencapai $42,99 \%$ dari total nilai ekspor perikanan Indonesia ke seluruh dunia namun terjadi tren penurunan ekspor sebesar 4,51\% per tahun sedangkan Amerika Serikat menempati peringkat kedua dengan persentase sebesar 23,27 \% dengan pertumbuhan positif sebesar $14,4 \%$ per tahunnya.

Komoditas ekspor perikanan Indonesia pada umumnya adalah udang, tuna, rumput laut, mutiara, ikan hias dan ikan lainnya dan yang utama adalah tuna dan udang. Berdasarkan penelitian yang dilakukan oleh Mutakin (2008) bila dilihat dari sektor pertanian, peran komoditas perikanan khususnya udang pada tahun 2007 mencapai $26,71 \%$ dari total ekspor komoditas pertanian, sementara itu untuk biji coklat sebesar 17,86\% dan kopi sebesar $16,23 \%$. Untuk komoditas udang, ekspor Indonesia paling banyak ke pasar Jepang. Tercatat nilai ekspor udang Indonesia sekitar US\$ 794.795.322 pada tahun 2007. Uni Eropa merupakan pasar tujuan ekspor ke-3 bagi udang Indonesia dan menyerap sekitar $15 \%$ dari volume ekspor udang nasional. Komoditas perikanan lainnya yang menjadi unggulan adalah tuna. Potensi ikan tuna secara nasional mencapai sekitar 1.165,35 ribu ton. Pada tahun 2007, nilai ekspor tuna Indonesia sebesar US\$152.407.815.

\section{METODE PENELITIAN}

\section{Model Operasional Penelitian}

Untuk menganalisis faktor-faktor yang berpengaruh terhadap perdagangan produk sektor perikanan Indonesia, digunakan model gravity dari Managi, et al. (2005) yang kemudian dilakukan modifikasi pada variabel dummy dan jarak. Pada model Managi, variabel ekspor dipengaruhi oleh pendapatan perkapita, jumlah penduduk, nilai tukar mata uang riil, jarak relatif dan besarnya pajak ekspor. Model yang digunakan adalah sebagai berikut:

$\operatorname{EXPR}_{\mathrm{ijt}}=\beta_{0}$ GDPIN $_{\mathrm{it}}{ }^{\beta 1} \operatorname{GDPJN}_{\mathrm{jt}}{ }^{\beta 2} \mathrm{POPI}_{\mathrm{it}}{ }^{\beta 3}$ POPJ $_{j \mathrm{tt}}{ }^{\beta 4} \mathrm{RERI}_{\mathrm{it}}{ }^{\beta 5} \mathrm{RERJ}_{\mathrm{jt}}{ }^{\beta 6} \mathrm{DR}_{\mathrm{ij}}{ }^{\beta 7} \exp \left(\beta_{8} \mathrm{TFAP}^{+}\right.$ $\beta_{9}$ TFAS) $\varepsilon_{\mathrm{ijt}}$

atau dapat ditulis dalam bentuk logaritma natural sebagai berikut :

Ln EXPR ${ }_{\text {iit }}=\beta_{0}+\beta_{1}$ Ln GDPIN $_{\text {it }}+\beta_{2}$ Ln GDPJN $_{\mathrm{jt}}+\beta_{3}$ Ln POPI $_{\mathrm{it}}+\beta_{4}$ Ln POPJ $_{\mathrm{jt}}+$

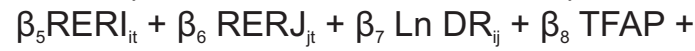
$\beta_{9}$ TFAS $+\varepsilon_{\mathrm{ijt}}$

dimana:

$\beta_{0} \quad$ : Intersep

$\beta_{1}, \beta_{2}, \ldots \beta_{10}$ : Koefisien variabel-variabel independen yang akan diuji secara statistik dan ekonometrik.

t : Periode tahun 1996-2007

EXPR $_{\text {it }}$ : Nilai ekspor komoditas

GDPIN $_{\text {it }}$ : Gross Domestic Product (GDP) nominal Indonesia pada tahun $\mathrm{t}$ (Milyar USD)

GDPJN $_{\mathrm{jt}}$ : Gross Domestic Product (GDP) nominal dari negara partner dagang j pada tahun t (Milyar USD)

POPI $_{\text {it }} \quad$ : Jum lah penduduk Indonesia pada tahun $\mathrm{t}$ (orang)

POPJ $_{\mathrm{jt}} \quad$ : Jumlah penduduk negara partner dagang j pada tahunt (orang)

RERI $_{\text {it }} \quad$ : Nilai tukar riil efektrif Indonesia pada tahun $\mathrm{t}$ (tahun dasar $2000=100$ )

RERJ $_{\text {jt }} \quad$ : Nilai tukar riil importir negara j pada tahun $\mathrm{t}$ (tahun dasar $2000=100$ ) 
$\operatorname{Dr}_{\mathrm{ij}} \quad$ : Jarak relatif antara ibukota Indonesia (Jakarta dengan negara partner dagang $\mathrm{j}(\mathrm{Km})$. Jarak relatif dihitung dengan menggunakan rumus:

$$
D R=\text { Jarak } x \frac{\text { GDPIndonesia }}{\text { GDPnegara partner dagang }}
$$

TFAP : Interaksi antara tarif WTO dengan variabel dummy negara-negara APEC, bernilai 1 jika partner dagang termasuk anggota APEC dan 0 untuk bukan anggota (\%)

TFAS : Interaksi antara tarif WTO dengan variabel dummy negara-negara ASEAN, bernilai 1 jika partner dagang termasuk anggota ASEAN dan 0 untuk bukan anggota (\%)

$\varepsilon_{\mathrm{ij}} \quad:$ Galat/error

\section{Jenis dan Sumber Data}

Jenis data yang digunakan dalam penelitian adalah data sekunder, dengan cakupan sebagai berikut:

a.Data agregat nilai ekspor komoditas perikanan Indonesia ke berbagai negara diperoleh dari UN Comtrade dengan menggunakan data Harmmonized System 92 (HS-92). Data komoditas yang digunakan sebagai berikut :

a. Kode HS03: komoditas ikan, udang, kepiting, binatang air berkulit lunak, dan hewan air invertebrata lainnya.

b. Kode HS1603: ekstraksi ikan dan hewan hewan air invertebrata;

c. Kode HS1604: Ikan olahan, telur ikan/caviar.

d. Kode HS1605: Kepiting dan hewan lunak yang diolah.

e. Kode HS121220: Rumput laut dan alga lainnya.

f. Kode HS710110: mutiara alami hasil dari tangkap laut.

g. Kode Hs71012: mutiara hasil dari budidaya yang belum diolah menjadi perhiasan. h. Kode HS710122: mutiara hasil dari budidaya yang sudah diolah menjadi perhiasan.

Data kemudian dibagi dengan CPI untuk memperoleh nilai ekspor riil komoditas perikanan. Negara-negara yang menjadi mitra dagang berjumlah 28 negara yaitu: Jepang, AS, Singapura, China, Hongkong, Thailand, Inggris, Belgia, Malaysia, Belanda, Korea Selatan, Prancis, Jerman, Australia, Kanada, Italia, Spanyol, Filipina, Mesir, Saudi Arabia, Denmark, Sri Lanka, Swedia, Swiss, Polandia, Yunani, Selandia Baru dan Siprus. Dasar yang digunakan dalam penentuan negara ini berdasarkan :

1. Pasar produktif: Jepang, Amerika Serikat, dan Uni Eropa;

2. Pasar prospektif: China, Korea Selatan, Australia, Selandia Baru;

3. Pasar potensial: negara-negara lainnya (DKP, 2008) dan jumlah nilai ekspor dari 28 negara tersebut mencapai sekitar $96,87 \%$ dari total nilai ekspor Indonesia ke seluruh dunia. Periode waktu yang akan dilihat adalah selama 12 tahun yakni dari tahun 1996 hingga tahun 2007 karena data tarif WTO ada dari tahun 1996.

\section{b. GDP (Gross Domestic Product)}

Data GDP yang digunakan adalah data GDP nominal yang diperoleh dari World Development Indicator (WDI) dari World Bank.

c. CPI (ConsumerPrice Index)

Data CPI diperoleh dari International Financial Statistics (IFS).

d. Jumlah penduduk

Data jumlah penduduk diperoleh dari IFS.

e. Nilai tukar riil efektif

Data nilai tukar riil efektif diperoleh dari IFS

f. Jarak

Data jarak antara negara Indonesia dengan mitra dagangnya (dengan pendekatan ibukota negara) dalam satuan kilometer diperoleh dari situs http:// www.indo.com/distance. 
g. Tarif

Data tarif yang digunakan merupakan tarif dari World Trade Organization (WTO) dari situs: http://www.wto.org. Tarif yang digunakan dalam penelitian ini adalah tarif ad valorem yaitu tarif yang dikenakan berdasarkan persentase tertentu dari nilai barang-barang yang diimpor.

h. Negara-negaraASEAN

Negara-negara yang termasuk dalam ASEAN adalah Indonesia, Singapura, Thailand, Malaysia, Brunei, Kamboja, Laos, Vietnam, Myanmar dan Filipina.

I. Negara-negara APEC

Negara-negara yang termasuk dalam APEC adalah Australia, Brunei Darussalam, Kanada, Indonesia, Jepang, Korea Selatan, Malaysia, Selandia Baru, Filipina, Singapura, Thailand, Amerika Serikat, China, Hongkong, Taiwan, Meksiko, Papua Nugini, Chili, Peru, Russia dan Vietnam.

\section{Metode Analisis Data}

Metode analisis yang digunakan dalam kajian ini adalah metode regresi data panel. Data penampang lintangnya adalah 28 negara mitra dagang dan data deret waktu 12 tahun (1996-2007). Diagram alur pengolahan data dengan menggunakan metode regresi data panel dapat dilihat pada Gambar 1.

\section{Validasi Model Penelitian}

Untuk memilih model data panel yang akan digunakan baik itu pooled least square/common effect, fixed effect atau random effect maka dilakukan beberapa uji yaitu :

a. Uji Chow untuk menentukan apakah menggunakan common effect atau fixed effect;

b. Uji Hausman untuk menentukan pilihan model fixed effect atau random effect; dan terakhir adalah

c. uji LM untuk memilih menggunakan struktur covarian heteroskedastis atau homoskedastis.

Hasil ketiga uji tersebut dapat dilihat pada Tabel 1.

Uji Chow ini mengikuti distribusi $\mathrm{F}$ dengan df $1=27$ dan df $2=299$. Berdasarkan Tabel 1 , nilai $\mathrm{F}$ tabelnya adalah 1,$34 ; 1,46 ;$ dan 1,70 untuk masing-masing tingkat kepercayaan 10 $\%, 5 \%$ dan $1 \%$. Karena nilai Chow Test $>$ nilai $\mathrm{F}$ tabel untuk tingkat kepercayaan berapa pun maka maka $\mathrm{H}_{0}$ ditolak sehingga model yang digunakan adalah Fixed Effect Model.

Uji Hausman digunakan untuk menentukan penggunaan Fixed Effect Model atau Random Effect Model. Uji Hausman sofwert-sofwert Eview maka dihasilkan nilai sebesar 23,90. Uji Hausman ini mengikuti distribusi statistik Chi Square dengan derajat kebebasan (degree of freedom) sebanyak k-1 dimana k adalah jumlah variabel bebas. Nilai dari $\left.X^{2}{ }_{8}\right)=20,0902 ; 15,5073$; dan 13,3616 untuk tingkat kepercayaan masing-masing sebesar $1 \%$, $5 \%$ dan $10 \%$. Karena nilai dari uji Hausman $>\mathrm{X}^{2}{ }_{8}$ ) untuk tingkat kepercayaan berapapun maka $\mathrm{H}_{0}$ ditolak sehingga model terbaik yang dapat digunakan adalah Fixed Effect Model. Berdasarkan pendapat pakar ekonometrika juga menyatakan bila $\mathrm{N}$ (jumlah cross section) > T (jumlah time series) maka model yang digunakan adalah Fixed Effect Model.

Tabel 1. Hasil Uji Untuk Pemilihan Model Data Panel

Table 1. Result of of the Test Choos Data Panel Model

\begin{tabular}{|c|c|c|c|c|c|}
\hline \multirow[t]{2}{*}{ No } & \multirow{2}{*}{$\begin{array}{c}\text { Jenis uji } \\
\text { (Type of test) }\end{array}$} & \multirow{2}{*}{$\begin{array}{c}\text { Nilai Uji } \\
\text { (Test value) }\end{array}$} & \multicolumn{3}{|c|}{$\begin{array}{l}\text { Tingkat kepercayaan } \\
\text { (Significance leve/) (a) }\end{array}$} \\
\hline & & & $\alpha=10 \%$ & $\alpha=5 \%$ & $\alpha=1 \%$ \\
\hline 1 & Uji Chow (Chow Test) & 10,43 & 1,34 & 1,46 & 1,70 \\
\hline 2 & Uji Hausman(Hausman Test) & 23,90 & 13,36 & 15,51 & 20,09 \\
\hline 3 & Uji LM (LM Test) & 124,62 & 36,74 & 40,11 & 46,96 \\
\hline
\end{tabular}

Sumber : data primer (diolah)/Source : primary data (processed) 


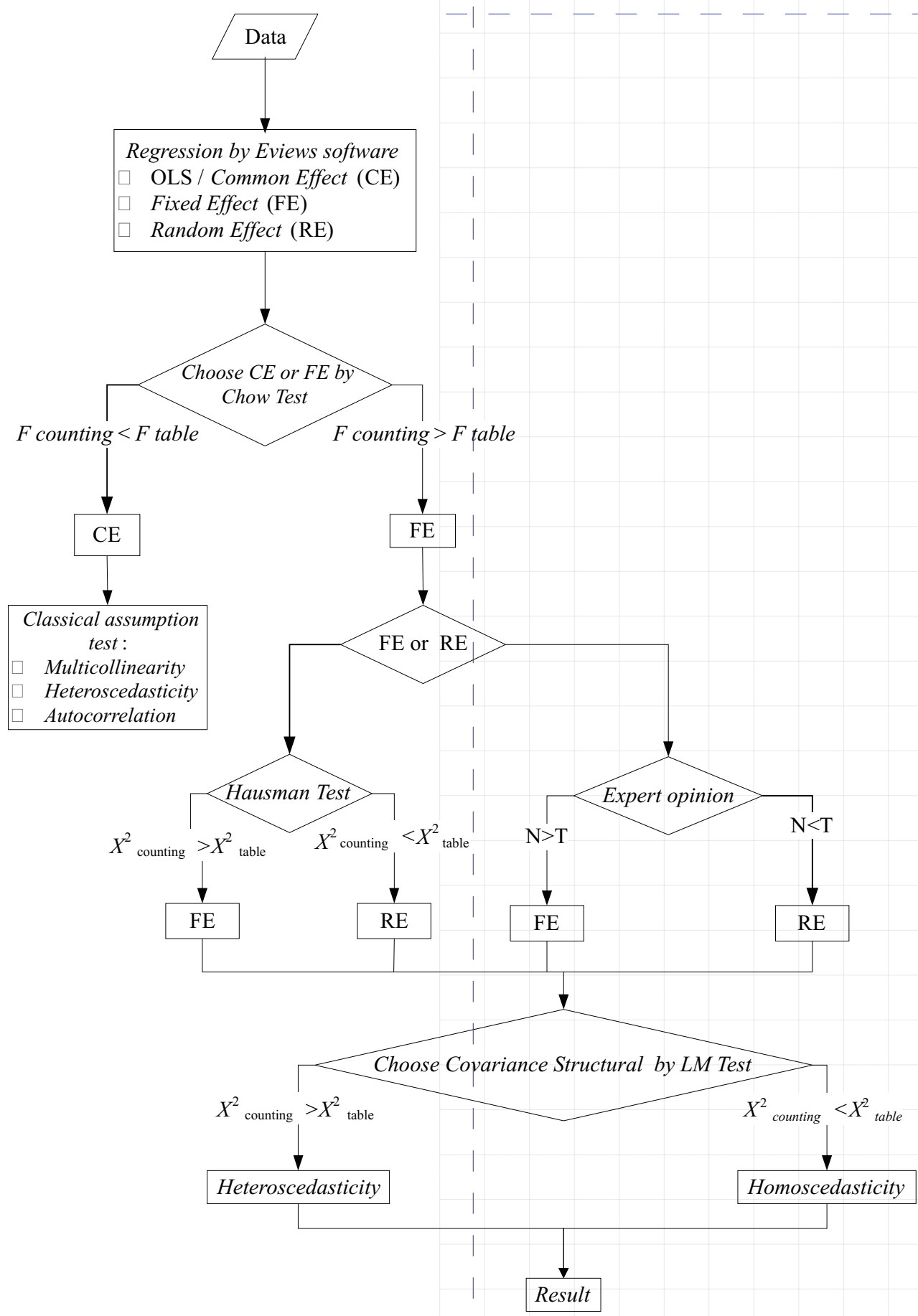

Gambar 1. Diagram Alir Metode Regresi Data Panel Analisis Ekspor Komoditas Perikanan Indonesia

Figure 1. Flow Chart of Panel Data Regression Method in the Analysis of Indonesian Fisheries Commodities Export 
Model Fixed Effect Model selanjutnya dilakukan dengan uji LM test untuk mengetahui model nilai ekspor perikanan Indonesia terdapat gejala heteroskedastisitas atau homoskedastisitas. Hal ini disebabkan karena intersep antar individu berbeda antar individu tapi intercept tidak memiliki variasi antar waktu. Berdasarkan uji LM maka dihasilkan nilainya sebesar 124,6244. Uji LM ini mengikuti distribusi $X^{2}$ dengan derajat kebebasan $\mathrm{N}-1$ dimana $\mathrm{N}$ adalah jumlah cross section sebesar 28 sehingga df $=27$. Nilai $X^{2}$ dari tabel adalah sebesar 46,9630; 40,1133; dan 36,7412 untuk tingkat kepercayaan masing-masing sebesar $1 \%, 5 \%$ dan $10 \%$. Karena nilai uji LM $>X^{2}$ tabel untuk tingkat kepercayaan berapa pun maka $\mathrm{H}_{0}$ ditolak sehingga pada model terdapat gejala heteroskedastis. Oleh karena itu untuk menghilangkan gejala tersebut dipilih struktur Kovariansi heteroskedastis dan menggunakan Weighted Least Square pada model.

\section{Hasil Estimasi Model}

Berdasarkan hasil estimasi dengan menggunakan Fixed Effect dengan Weighted
Least Square diperoleh nilai koefisien untuk seluruh variabel bebas seperti yang terlihat dalam Tabel 2.

Sehingga persamaan model nilai ekspor perikanan Indonesia dapat dituliskan sebagai berikut :

$\log (E X P R)=74,15+4,82 \log ($ GDPIN $)+1,03$ $\log ($ GDPJN $)-13,70 \log (P O P I)-2,52$ Log(POPJ) -0,11 Log(RERI)-0,37 Log (RERJ) $-4,68 \log (\mathrm{DR})+0,09$ TFAP $-0,06$ TFAS

Nilai koefisien determinasi $\left(R^{2}\right)$ dari estimasi model sebesar 95,87 \%. Hal ini menunjukkan bahwa sekitar 95,87\% peubah dependen dapat dijelaskan secara baik oleh variabel-variabel independennya. Sedangkan sisanya sebesar 4,13 \% diterangkan oleh variabel-variabel lainnya yang tidak terdapat dalam model. Nilai $R^{2}$ yang tinggi menunjukkan bahwa spesifikasi model sudah tepat dalam pemilihan peubah.

Berdasarkan uji t, variabel Log (RERI) tidak signifikan dalam mempengaruhi model karena nilai probabilitinya lebih besar daripada

Tabel 2. Hasil Estimasi Fixed Effects Model (Cross Section Weights)

Table 2. Estimation result of Fixed Effects Model (Cross Section Weights)

\begin{tabular}{c|rrcc}
\hline Variable & Coefficient & t-statistics & Prob & Significance \\
\hline C & 74,15 & 2,50 & 0,013 & $* *$ \\
Log(GDPIN) & 4,82 & 1,73 & 0,084 & $*$ \\
Log(GDPJN) & 1,03 & 5,11 & 0,000 & $* * *$ \\
Log(POPI) & 13,70 & $-2,15$ & 0,032 & $* *$ \\
Log(POPJ) & $-2,52$ & $-2,82$ & 0,005 & $* *$ \\
Log(RERI) & $-0,11$ & $-0,44$ & 0,663 & ts \\
Log(RERJ) & $-0,37$ & $-2,14$ & 0,033 & $*$ \\
Log(DR) & $-4,68$ & $-1,68$ & 0,093 & $*$ \\
TFAP & 0,09 & 3,21 & 0,002 & $* *$ \\
TFAS & $-0,06$ & $-2,17$ & 0,030 & $* *$ \\
\hline
\end{tabular}

$R^{2}=95,87 \%$

Prob (F-statistic) $=0,000000$

notes :

ts : not significant; ${ }^{* \star *}$ : significant at $\alpha=1 \% ;{ }^{* *}$ : significant at $\alpha=5 \% ;{ }^{*}$ : significant at $\alpha=10 \%$ 
tingkat kepercayaan $\alpha=1 \%, 5 \%$ dan $10 \%$ sehingga hipotesis $\mathrm{H}_{0}$ diterima artinya variabel tersebut tidak berpengaruh terhadap nilai ekspor. Bila dilakukan regresi terpisah antara variabel Log(EXPR) dengan variabel Log(RERI) dengan menggunakan OLS maka hasilnya signifikan (Probabiliti sebesar 0,0000) dengan nilai koefisien sebesar 0,93. Ketidaksignifikanan dari variabel Log(RERI) ini disebabkan karena dipengaruhi oleh variabel independen lain dalam model.

Untuk variabel-variabel lainnya seperti Log(GDPIN) dan Log(DR) berpengaruh signifikan di $\alpha=10 \%$, variabel intercept, Log(POPI), Log(RERJ), dan TFAS berpengaruh signifikan di $\alpha=5 \%$. Variabel Log(GDPJN), Log(POPJ), dan TFAP berpengaruh signifikan di $\alpha=1 \%$. Tandatanda koefisien pada variabel yang signifikan namun tidak sesuai dengan hipotesis terdapat pada variabel Log(POPJ) dan TFAP.

Nilai probabiliti F-statistic sebesar 0.000000 dan nilainya kurang dari tingkat kepercayaan a berapa pun sehingga menurut uji $F$, hipotesis $H_{0}$ ditolak artinya secara bersama-sama variabel-variabel independent mempengaruhi nilai ekspor.

\section{Interpretasi Hasil Estimasi}

Berdasarkan hasil estimasi, kenaikan $1 \%$ pada GDP nominal Indonesia menyebabkan kenaikan nilai ekspor perikanan sebesar $4,82 \%$. Hal ini sesuai dengan hipotesis dimana terdapat hubungan positif antara GDP nominal Indonesia dengan nilai ekspornya. Untuk kenaikan $1 \%$ pada GDP nominal mitra dagang menyebabkan kenaikan sebesar 1,03 $\%$ pada nilai ekspor dan hal ini juga sesuai dengan hipotesis. Dengan adanya sinyal positif pertumbuhan GDP domestik dan mitra dagang diharapkan dapat lebih meningkatkan nilai ekspor komoditas perikanan Indonesia.

Untuk kenaikan $1 \%$ pada jumlah penduduk Indonesia dapat menyebabkan penurunan jumlah nilai ekspor perikanan sebesar 13,70 \%. Hubungan negatif yang terjadi antara jumlah penduduk Indonesia dengan nilai ekspor perikanan sudah sesuai dengan hipotesis penelitian. Sedangkan untuk kenaikan $1 \%$ populasi penduduk mitra dagang menyebabkan penurunan nilai ekspor sebesar $2,52 \%$. Hal ini tidak sesuai dengan hipotesis dimana seharusnya terdapat hubungan positif. Faktor yang dapat menyebabkan hal tersebut adalah: (i) melemahnya harga rata - rata komoditas perikanan di pasar internasional sebagai akibat meningkatnya produksi; (ii) hambatan dalam perdagangan seperti isu dumping dan hambatan non tarif seperti Zero Tolerance dan Bioterrorism Act; 3). Komoditas perikanan Indonesia yang diekspor kurang memiliki nilai tambah (Yusuf dan Tajerin, 2007).

Faktor-faktor ini yang menyebabkan terjadi pergeseran preferensi dari mitra dagang sehingga Indonesia tidak menjadi negara utama pengekspor komoditas perikanan ke Amerika Serikat dan Jepang yang merupakan pasar utama komoditas perikanan. Untuk pasar Jepang posisi Indonesia berada di urutan ke lima berdasarkan besarnya proporsi nilai impor Jepang seperti pada Tabel 3. Pasar Amerika Serikat, Indonesia menempati posisi ke enam untuk negara pengekspor komoditas perikanan seperti yang terlihat pada Tabel 4 .

Dengan posisi Indonesia sebagai negara eksportir tersebut, variabel jumlah penduduk mitra dagang tidak sesuai dengan hipotesis. Jika terjadi depresiasi atau melemahnya rupiah sebesar $1 \%$ pada nilai tukar riil efektif Indonesia maka dapat menyebabkan nilai ekspor perikanan menurun sebesar $0,11 \%$. Namun menurut uji t, variabel RERI tidak signifikan dalam mempengaruhi nilai ekspor perikanan Indonesia.

Bila terjadi kenaikan $1 \%$ pada nilai tukar riil efektif mitra dagang atau dengan kata lain nilai tukar riil efektifnya mengalami apresiasi maka dapat menyebabkan penurunan nilai ekspor sebesar $36,78 \%$. Hal ini sejalan dengan hipotesis dimana terdapat hubungan negatif antara nilai tukar riil efektif mitra dagang dengan nilai ekspor perikanan 
Tabel 3. Rata-rata Nilai Impor Jepang dan Besarnya Proporsi Berdasarkan Negara Tujuan Impor, Tahun 1996-2007

Table 3. Average of Import Value on Japanese Fisheries Product and Share Based on Destination Country, 1996-2007

\begin{tabular}{llrc}
\hline No & Negara / Country & $\begin{array}{c}\text { Nilai Impor / Import } \\
\text { Value (US\$) }\end{array}$ & $\begin{array}{c}\text { Besarnya Proporsi/ } \\
\text { Share Based }\end{array}$ \\
\hline 1 & China/China & $2,538,974.02$ & 17.49 \\
2 & Amerika Serikat/United States & $1,422,199,57$ & 9.80 \\
3 & Rusia/Russia & $1,060,794,27$ & 7.31 \\
4 & Thailand/Thailand & $996,041,92$ & 6.86 \\
$\mathbf{5}$ & Indonesia/Indonesia & $\mathbf{9 4 4 , 9 8 8 , 3 8}$ & $\mathbf{6 . 5 1}$ \\
6 & Korea Selatan/South Korea & $843,125,28$ & 5.81 \\
7 & Kanada/Canada & $349,036,37$ & 2.40 \\
8 & Negara Lainnya/Other Country & $6,362,228,39$ & 43.82 \\
& Dunia/World & $14,517,38822$ & 100 \\
\hline
\end{tabular}

Sumber : Data dari UN Comtrade, 2009 (diolah)/Source : UN Comtrade, 2009 (processed)

Tabel4. Rata-rata Nilai Impor Amerika Serikat dan Besarnya Proporsi Berdasarkan Negara Tujuan Impor Tahun 1996-2007

Table 4. Average of Import Value of United States Fisheries Product and Share Based on Destination Country, 1996-2007

\begin{tabular}{clrr}
\hline No & Negara / Country & $\begin{array}{r}\text { Nilai Impor / } \\
\text { Import Value (US\$) }\end{array}$ & $\begin{array}{c}\text { Besarnya Proporsi/ } \\
\text { Share Based }\end{array}$ \\
\hline 1 & Kanada/Canada & $1,878,091.44$ & 16.94 \\
2 & Thailand/Thailand & $1,555,926.65$ & 14.03 \\
3 & China/China & $1,041,223.55$ & 9.39 \\
4 & Chile/Chile & $653,221.16$ & 5.89 \\
5 & Ekuador/Ecuador & $555,236.30$ & 5.01 \\
$\mathbf{6}$ & Indonesia/Indonesia & $\mathbf{5 0 8 , 5 1 9 . 6 3}$ & $\mathbf{4 . 5 9}$ \\
7 & Meksiko/Mexico & $475,533.51$ & 4.23 \\
8 & Jepang/Japan & $287,400.98$ & 2.59 \\
9 & Negara Lainnya/Other Country & $4,132,982.80$ & 37.27 \\
& Dunia/World & $11,088,136.00$ & 100 \\
\hline
\end{tabular}

Sumber : Data dari UN Comtrade, 2009 (diolah)/Source : UN Comtrade, 2009 (processed)

Indonesia. Untuk variabel jarak relatif, bila terdapat kenaikan sebesar $1 \%$ pada jarak relatif maka akan terjadi penurunan nilai ekspor sebesar 4,68 \%. Hal ini sudah sesuai dengan hipotesis karena terdapat hubungan negatif antara jarak dan nilai ekspor.

Kennedy (1981) menyatakan bahwa untuk menjelaskan interpretasi variabel semilog maka digunakan rumus sebagai berikut $g^{*}=\exp \left(\hat{c}-\frac{1}{2} V(\hat{c})\right)-1$ dimana $c$ adalah nilai koefisen variabel dummy dan
$V(\hat{c})$ merupakan variansi dari $(\hat{c})$ untuk Variabel interaksi tarif dengan dummy. Sedangkan integrasi ASEAN memiliki koefisien sebesar 0,062. Dengan demikian diperoleh $g^{*}=\mathbf{- 6 , 0 8}$ yang berarti bahwa tarif yang berlaku di negara ASEAN memberikan penurunan nilai ekspor sebesar $6,08 \%$ dan sesuai dengan hipotesis. Sedangkan untuk integrasi APEC koefisiennya adalah sebesar 0,087 sehingga $g^{*}=\mathbf{9 , 0 8}$ yang berarti bahwa tarif yang berlaku di negara APEC 
meningkatkan nilai ekspor perikanan sebesar $9,08 \%$ dengan tanda yang diperoleh tidak sesuai dengan hipotesis. Hal tersebut menunjukkan bahwa meskipun terdapat kenaikan tarif dari negara - negara yang tergabung dalam APEC, Indonesia cenderung meningkatkan ekspor. Hal ini didorong karena tujuan ekspor perikanan Indonesia lebih banyak ke Amerika Serikat dan Jepang yang memang merupakan anggota APEC. Untuk variabel nilai tukar riil efektif Indonesia meskipun mengalami depresiasi tetapi tidak signifikan dalam mempengaruhi nilai ekspor perikanan Indonesia.

Efek individu yang dihasilkan dari estimasi dengan Fixed Effect Model merupakan gambaran heterogenitas setiap negara (Agustina, 2008). Adanya heterogenitas tersebut memberikan arti bahwa terdapat faktor-faktor yang dimiliki oleh suatu negara tetapi tidak terdapat di negara lain. Dengan demikian negara tersebut memiliki suatu ciri khas yang unik yang tercermin dalam variabel lain. Dari hasil estimasi diperoleh bahwa fixed effect memperlihatkan perbedaan antara negara tujuan ekspor yang satu dengan yang lainnya terhadap rata-rata, sedangkan intercept menunjukkan nilai dari masingmasing negara tujuan ekspor. Negara yang memiliki nilai paling kecil (atau negatif) terhadap rata-rata akan memiliki intercept yang kecil dan sebaliknya, bila negara tersebut memiliki nilai yang besar terhadap rata-rata akan memiliki intercept yang besar. Efek individu dengan fixed effect dapat dilihat pada Tabel5.

Besar kecilnya nilai intercept pada Tabel 5 memberikan gambaran mengenai negara-negara yang berpotensi sebagai tujuan ekspor. Berdasarkan hasil estimasi lima

Tabel 5. Negara-Negara yang Berpotensi Sebagai Tujuan Ekspor Berdasarkan Efek Individu

Table 5. Countries Potentially to be Export Destination Based on Individual Effect

\begin{tabular}{cl|c}
\hline No & Negara/Country & $\begin{array}{c}\text { Nilai ekspor I } \\
\text { Export value (000 USD) }\end{array}$ \\
\hline 1 & Amerika Serikat/United States & 84,501 \\
\hline 2 & China/China & 81,530 \\
3 & Mesir/Egypt & 78,946 \\
4 & Inggris/England & 78,804 \\
\hline 5 & Jepang/Japan & 78,676 \\
6 & Jerman/Germany & 77,972 \\
7 & Perancis/France & 77,949 \\
8 & Kanada/Canada & 77,739 \\
\hline 9 & Spanyol/Spain & 77,062 \\
10 & Italia//talia & 76,592 \\
11 & Belanda/Netherland & 76,086 \\
\hline 12 & Belgia/Belgium & 75,864 \\
13 & Saudi Arabia/Saudi Arabia & 74,082 \\
15 & Filipina/Philippines & 73,812 \\
\hline 16 & Korea Selatan/South Korea & 73,324 \\
\hline 18 & Polandia/Poland & 72,974 \\
\hline
\end{tabular}


Lanjutan Tabel 5/Continued Table 5

\begin{tabular}{|c|c|c|}
\hline No & Negara / Country & $\begin{array}{c}\text { Nilai ekspor I } \\
\text { Export value (000 USD) }\end{array}$ \\
\hline 19 & Australia/Australia & 72,399 \\
\hline 20 & Swedia/Sweden & 71,999 \\
\hline 21 & Sri Lanka/Sri Lanka & 71,905 \\
\hline 22 & Yunani/Greece & 71,826 \\
\hline 23 & Swiss/Switzerland & 71,202 \\
\hline 24 & Hong Kong/Hong Kong & 69,905 \\
\hline 25 & Malaysia/Malaysia & 67,962 \\
\hline 26 & Selandia Baru/New Zealand & 67,838 \\
\hline 27 & Syprus/Cyprus & 66,663 \\
\hline 28 & Singapura/Singapore & 63,401 \\
\hline
\end{tabular}

Sumber : Data dari UN Comtrade, 2009 (diolah)/Source: UN Comtrade, 2009 (processed)

negara dengan nilai intercept terbesar yaitu Amerika Serikat, Cina, Mesir, Inggris dan Jepang merupakan negara potensial sebagai tujuan ekspor komoditas perikanan Indonesia. Sementara lima negara yang memiliki intercept terkecil yaitu: Hongkong, Malaysia, Selandia Baru, Siprus dan Singapura kurang potensial sebagai tujuan ekspor komoditas perikanan.

\section{KESIMPULAN DAN IMPLIKASI KEBIJAKAN}

\section{Kesimpulan}

Dari hasil analisis model ekspor perikanan Indonesia dengan menggunakan pendekatan gravitasi model dapat disimpulkan sebagai berikut.

1. Variabel-variabel yang signifikan dalam mempengaruhi nilai ekspor komoditas perikanan Indonesia adalah GDP nominal Indonesia (GDPIN), GDP nominal negara partner dagang (GDPJN), jarak relatif (DR), Intercept, populasi penduduk Indonesia (POPI), populasi penduduk negara partner dagang (POPJ), nilai tukar riil efektif negara partner dagang (RERJ), tarif di negara ASEAN (TFAS) dan tarif di negara APEC (TFAP).
2. Tanda - tanda koefisien pada variabel yang signifikan namun tidak sesuai dengan hipotesis terdapat pada variabel (POPJ) dan TFAP.

3. Variabel-variabel yang tidak signifikan dalam mempengaruhi model adalah nilai tukar riil efektif Indonesia (RERI).

4. Faktor - faktor yang memiliki hubungan positif yang mendorong peningkatan ekspor perikanan Indonesia adalah GDP nominal Indonesia, GDP nominal negara partner dagang, dan tarif dari anggota-anggota APEC sedangkan yang memiliki hubungan negatif adalah populasi penduduk Indonesia, populasi penduduk negara mitra dagang, jarak relatif, nilai tukar riil efektif mitra dagang dan tarif negara ASEAN. Lima negara yang potensial sebagai tujuan ekspor komoditas perikanan Indonesia adalah Amerika Serikat, Cina, Mesir, Inggris dan Jepang sedangkan negara Hongkong, Malaysia, Selandia Baru, Siprus dan Singapura kurang potensial sebagai tujuan ekspor komoditas perikanan Indonesia.

\section{Implikasi Kebijakan}

Hasil dari analisis model ini dapat digunakan sebagai bahan masukan untuk kebijakan sektor perikanan khususnya pada ekspor komoditas perikanan. Kebijakan 
tersebut sangat erat kaitannya dengan kebijakan di bidang fiskal, demografi dan moneter sehingga kebijakan yang dimunculkan perlu melibatkan berbagai pihak yang terkait.

\section{DAFTAR PUSTAKA}

Agustina, W. 2008. Ekspor Synthetic Staple Fibre Polyester (PSF) Indonesia ke Negara-Negara Non Uni Eropa. Tesis IImu Ekonomi Pasca Sarjana Fakultas Ekonomi Universitas Indonesia. Jakarta.

Annonmous. 2008. Indonesian Fisheries Book. Ministry of Marine Affairs and Fisheries - Japan Internationa Cooperation Agency (JICA). Japan

Kennedy, P. E. 1981. Estimation with Correctly Interpreted Dummy Variables in Semilogarithmic Equations. The American Economic Review. 71 (4). $801 p$.

Kusumastanto, T. 2002. Reposisi "Ocean Policy" dalam Pembangunan Ekonomi Indonesia di Era Otonomi Daerah. Orasi IImiah : Guru Besar Tetap Bidang IImu Kebijakan Ekonomi Perikanan dan Kelautan, Fakultas Perikanan dan IImu Kelautan, IPB. Bogor. 134 hal.
Managi, S., Kawajiri, H. and Tsurumi, T. 2005. Regional Economic Integration and Trade : An Empirical Evaluation of NAFTA and $E U$. International Journal Agricultural Resources, Governance and Ecology, 4 (1). $23 p$

Mutakin, F. 2008. Faktor Yang Menunjang Kinerja Ekspor Non Migas Indonesia Tahun 2008.Economic Review No. 211. http://www.bni.co.id/Portals/0/Document/ EKSPOR\% 20NON\%20MIGAS.pdf. Diakses tanggal 18 Maret 2009

Purnomo, A.H. 2007. Potret dan Strategi Pengembangan Perikanan Tuna, Udang dan Rumput Laut Indonesia Permasalahan Makro di Sektor Perikanan dan Alternatif Kebijakannya. Balai Besar Riset Sosial Ekonomi Kelautan dan Perikanan, Badan Riset Kelautan dan Perikanan, Departemen Kelautan dan Perikanan. Jakarta. 35 hal.

Yusuf, R. dan Tajerin. 2007. Strategi Pemasaran Komoditas Perikanan Indonesia. Balai Besar Riset Sosial Ekonomi Kelautan dan Perikanan. Jakarta. 22 hal. 


\section{Lampiran 1. Komoditi ekspor perikanan berdasarkan kode HS-92}

Appendix1. Fisheries Export Commodities Based on HS-92 Code

\begin{tabular}{|c|c|c|}
\hline No & HS-92 Code & Description \\
\hline \multirow[t]{12}{*}{1} & \multirow{2}{*}{$\begin{array}{l}03 \\
0301 \\
0302\end{array}$} & $\begin{array}{l}\text { Fish and crustaceans, molluscs and other aquatic invertebrate } \\
\text { Live Fish }\end{array}$ \\
\hline & & Fish, fresh or chilled, excluding fish fillets and other fish meat of \\
\hline & 0303 & $\begin{array}{l}\text { heading No. } 0304 \\
\text { Fish, frozen, excluding fish fillets and other fish meat of heading }\end{array}$ \\
\hline & & No. 0304 \\
\hline & 0304 & $\begin{array}{l}\text { Fish fillets and other fish meat (whether or not minced), fresh, chilled } \\
\text { or frozen }\end{array}$ \\
\hline & 0305 & \multirow{2}{*}{$\begin{array}{l}\text { Fish, dried, salted or in brine, smoked fish, whether or not cooked } \\
\text { before or during the smoking process; flours, meals and pellets of } \\
\text { fish, fit for human consumption }\end{array}$} \\
\hline & & \\
\hline & 0306 & \multirow{2}{*}{$\begin{array}{l}\text { Crustaceans, whether in shell or not, live, fresh chilled, frozen, dried, } \\
\text { salted or in brine, crustaceans, in shell, cooked by steaming or by } \\
\text { boiling in water, whether or not chilled, frozen, dried, salted or in } \\
\text { brine, flours, meals }\end{array}$} \\
\hline & & \\
\hline & 0307 & \multirow{3}{*}{$\begin{array}{l}\text { Molluscs, whether in shell or not, live, fresh chilled, frozen, dried, } \\
\text { salted or in brine; aquatic invertebrates other than crustaceans and } \\
\text { molluscs live, fresh chilled, frozen, dried, salted or in brine; flours, } \\
\text { meals and pellets }\end{array}$} \\
\hline & & \\
\hline & & \\
\hline 2 & 1603 & $\begin{array}{l}\text { Extracts and juices of fish, meat or crustaceans, molluscs and other } \\
\text { aquatic invertebrates }\end{array}$ \\
\hline 3 & 1604 & Prepared or preserved fish; caviar and caviar substitutes prepared \\
\hline 4 & 1605 & $\begin{array}{l}\text { from fish eggs } \\
\text { Crustaceans, molluscs and other aquatic invertebrates, prepared or } \\
\text { preserved }\end{array}$ \\
\hline 5 & 121220 & $\begin{array}{l}\text { Seaweeds and other algae, fresh, chilled, frozen or dried, whether or } \\
\text { not ground }\end{array}$ \\
\hline 6 & 710110 & \multirow{2}{*}{$\begin{array}{l}\text { Pearls, natural, whether or not worked or graded, but not strung, } \\
\text { mounted or set, natural pearls, temporarily strung for convenience of } \\
\text { transport (excl. mother-of-pearl) }\end{array}$} \\
\hline & & \\
\hline 7 & \multirow{2}{*}{$\begin{array}{l}710121 \\
710122\end{array}$} & \multirow{3}{*}{$\begin{array}{l}\text { Cultured pearls, unworked, whether or not graded } \\
\text { Cultured pearls, worked, whether or not graded, but not strung, } \\
\text { mounted or set, worked cultured pearls, temporarily strung for } \\
\text { convenience of transport }\end{array}$} \\
\hline 8 & & \\
\hline & & \\
\hline
\end{tabular}

